\title{
Chromosome 12q24.3 controls sensitization to cat allergen in patients with asthma from Siberia, Russia
}

\author{
Elena S. Gusareva a,b , Elena Ju. Braginac ${ }^{c}$ Svetlana N. Buinova ${ }^{\mathrm{d}}$, Boris A. Chernyak ${ }^{\mathrm{d}}$, \\ Valery P. Puzyrev ${ }^{\mathrm{c}, e}$, Ludmila M. Ogorodova ${ }^{\mathrm{f}}$, Marie Lipoldová a,b,* \\ a Institute of Molecular Genetics, Academy of Sciences of the Czech Republic v.vi.., Vídeňská 1083, 14220, Prague 4, Czech Republic \\ b Third Faculty of Medicine, Charles University, Ruská 87, 10000, Prague 10, Czech Republic \\ ${ }^{c}$ Research Institute of Medical Genetics, Siberian Branch of Russian Academy of Medical Sciences, Naberegnaya r. Ushayki, 10, 634050, Tomsk, Russia \\ ${ }^{\mathrm{d}}$ Department of Allergology and Pulmonology, Irkutsk State Institute for Post-graduate Medical Education, Yubileiniy 100, 664079, Irkutsk, Russia \\ e Siberian State Medical University, Department of Medical Genetics, Moskovsky trakt 2, 634050, Tomsk, Russia \\ ${ }^{\mathrm{f}}$ Faculty of Pediatrics, Siberian State Medical University, Moskovsky trakt 2, 634050, Tomsk, Russia
}

\section{A R T I C L E I N F O}

\section{Article history:}

Received 10 December 2008

Received in revised form 23 April 2009

Accepted 4 May 2009

Available online $\mathrm{xxx}$

\section{Keywords:}

Asthma

Cat allergens

Total and specific IgE

Siberian population

12q24

\begin{abstract}
A B S T R A C T
In Russian population of Siberia asthma is usually concomitant with high sensitization to indoor allergens (cat, dog and house dust mites), overproduction of total immunoglobulin E (IgE) and airway hyperreactivity. Definition of genes that predispose to development of various sub-components of the asthma phenotype is important for understanding of etiology of this disease. To map genes predisposing to asthma, we tested 21 microsatellite markers from candidate chromosomal regions in 136 Russian nuclear families with asthma from Siberia. We performed non-parametric analysis for linkage with asthma, total IgE, specific IgE to cat, dog, and dust mites, and spirometric indices (FEV1 (\%) - percentage of predicted forced expiratory volume in $1 \mathrm{~s}, \mathrm{FVC}(\%)$ - percentage of predicted forced vital capacity, and FEV1/FVC (\%) - Tiffenau index). The most significant linkage was to the candidate region on chromosome 12. Locus controlling cat-specific IgE, which is the most abundant in asthma patients from Siberian population, mapped within the interval between 136 and $140 \mathrm{cM}$ on chromosome 12q24.3, with the suggestive linkage at the marker D12S1611 (LOD = 2.23, $P=0.0007$ ). Total IgE was also linked to this region (D12S1611 $-\mathrm{LOD}=1.12$, $P=0.012$ ). FEV1 (\%) exceeded LOD $>1$ threshold for significance with the same locus $12 \mathrm{q} 24.3$, but with the peak at a more proximal region at $111.87 \mathrm{cM}(\mathrm{D} 12 \mathrm{~S} 338-\mathrm{LOD}=1.21, P=0.009)$. Some evidence of linkage (LOD > 1.0) was also detected for asthma at 6p21.31 (D6S291) and total IgE at 13q14.2 (D13S165). These data indicate that the locus $12 \mathrm{q} 24.3$ is the most promising candidate for identification of asthma genes in Russian population of Siberia.
\end{abstract}

(C) 2009 Elsevier B.V. All rights reserved.

\section{Introduction}

Atopy is an inherited predisposition to overproduction of immunoglobulin E (IgE) in response to common environmental allergens. It is the major risk factor for development of allergic diseases, the most severe of which is allergic bronchial asthma, a chronic inflammatory disease of airways characterized by air-flow limitations that cause recurrent episodes of wheezing, breathlessness, chest tightness, and cough. The reduced pulmonary function during asthma is usually caused by allergic reaction with elevated production of allergen-specific IgE and T helper 2 type cytokines,

\footnotetext{
* Corresponding author at: Institute of Molecular Genetics, Academy of Sciences of the Czech Republic v.v.i., Vídeňská 1083, 14220, Prague 4, Czech Republic. Tel.: +420 241063243; fax: +420 224310955 .

E-mail address: lipoldova@img.cas.cz (M. Lipoldová).
}

reversible bronchial obstruction, hypersecretion of mucus, and hyper-responsiveness of the airways to non-specific bronchospasmogenic stimuli [1]. Allergic asthma is a complex trait that is under control of multiple genes, the effects of which can be modulated by environmental factors. In the last decades a number of loci controlling traits associated with asthma and atopy have been identified. Several loci including 5q [2-6], 6p [4,7-9], 7p [7,10-12], 7q [2,5,12], 11q [7,11,12], 12q [2,5,6,13-17] and 16q [7,18,19] were corroborated in different human populations. Positional cloning indicated genes at six loci 2q14 (DPP10 - dipeptidyl serine protease) [20], 2q33 (CTLA4 - cytotoxic T-lymphocyte-associated-4 gene) [21], 5q32-33 (PCDH1 - protocadherin-1) [22], 7p14.3 (GPRA - G proteincoupled receptor) [23], 13q14 (PHF11 - PHD finger protein 11) [24], and 20p13 (ADAM33 - Zn-dependent metalloproteinase) [25] predisposing to asthma, atopy and airway hyper-responsiveness. Genome-wide association mapping led to identification of the genes ORMDL3 (an endoplasmic reticulum membrane protein) at

0165-2478/\$ - see front matter @ 2009 Elsevier B.V. All rights reserved. doi:10.1016/j.imlet.2009.05.003 
locus 17q21 [26] and CHI3L1 (chitinase 3-like 1) at locus 1q32.1 [27] that contribute to the risk of asthma.

Genetic heterogeneity of human populations and variability in environmental factors cause diversity in allergic sensitization in different geographical areas. Our previous study revealed that cat (e1), and also dog (e2), and dust mites (d1, d2) are the most prominent allergens in patients with allergic bronchial asthma from the Russian population of Siberia [28]. A later study provided evidence that early life exposure to cats increases the risk of asthma in Russians [29]. Definition of the genetic component of sensitization to the most prominent allergens and other asthma-associated traits (total IgE, pulmonary function) in Russian patients with asthma is therefore important for understanding of etiology of this disease in Siberian population. To define loci that contribute to susceptibility to asthma and atopy in Russian population from Siberia, we have selected a set of short tandem repeat (STR) markers (Table 1) from the most promising candidate chromosomal regions reported by others and have tested them for linkage with asthma, and traits often related to asthma: total IgE, specific IgE to cat (e1), dog (e2), and dust mite (d1 and d2) allergens, and pulmonary function represented by spirometric indices FEV1 (\%) - percentage of predicted forced expiratory volume in $1 \mathrm{~s}$, FVC (\%) - percentage of predicted forced vital capacity, and Tiffenau index - FEV1/FVC (\%).

\section{Material and methods}

\subsection{Families}

Nuclear families (136 families, $n=540$ ) of Russian ethnicity from Siberian cities Tomsk, Thumen and Irkutsk (Russia) were collected through probands registered in local clinics as patients with allergic bronchial asthma (Table 2). Asthma was diagnosed according to criteria of the Global Initiative for Asthma (GINA 2002 http://ginaasthma.org). All participants received a full explanation of the study design. Spirometric indices were measured according to ref. [30]. The clinical examination was approved by the local Ethical Committees.

Table 1

The list of markers tested for linkage with asthma, total IgE, specific IgE to cat (e1), dog (e2) and dust mites (d1 and d2) and spirometric indices (FEV1 (\%), FVC (\%) and FEV1/FVC (\%).

\begin{tabular}{|c|c|c|c|}
\hline Marker & Chromosome $^{\mathrm{a}}$ & cM (Marshfield) & Reference \\
\hline D2S308 & $2 q 14.1$ & 124.03 & [20] \\
\hline D5S816 & $5 q 31.1$ & 139.33 & [5] \\
\hline D5S1507 & $5 q 33.2$ & 157.57 & [3] \\
\hline D6S291 & $6 \mathrm{p} 21.31$ & 49.50 & [8] \\
\hline D7S2250 & 7p14.3 & 54.11 & {$[7,10,11]$} \\
\hline D7S821 & $7 q 21.3$ & 109.12 & \\
\hline D11S2006 & 11q12.1 & 59.24 & [31] \\
\hline D12S1298 & $12 q 14.1$ & 75.17 & \\
\hline D12S379 & $12 \mathrm{q} 21.31$ & 93.69 & {$[13,14]$} \\
\hline D12S1059 & $12 \mathrm{q} 23.1$ & 105.18 & \\
\hline D12S338 & $12 q 23.3$ & 111.87 & \\
\hline D12S1645 & $12 \mathrm{q} 24.11$ & 119.55 & \\
\hline D12S2082 & $12 q 24.22$ & 130.94 & \\
\hline D12S1282 & $12 q 24.3$ & 136.82 & \\
\hline D12S1611 & $12 q 24.3$ & 140.17 & \\
\hline D12S1634 & $12 \mathrm{q} 24.3$ & 148.24 & \\
\hline D13S165 & $13 q 14.2$ & 45.55 & [24] \\
\hline D16S3253 & $16 q 12.2$ & 71.77 & [7] \\
\hline D16S539 & $16 q 24.1$ & 124.73 & [18] \\
\hline D19S601 & $19 q 13.33$ & 83.19 & [32] \\
\hline D20S473 & $20 \mathrm{p} 13$ & 9.53 & [25] \\
\hline
\end{tabular}

a The chromosomal regions were found in the Ensembl Database (http://www. ensembl.org/index.html, November 13, 2008).
Table 2

Characterization of the Russian nuclear family group.

\begin{tabular}{|c|c|}
\hline Russian family group characteristics & Number (percentage) \\
\hline $\begin{array}{l}\text { Nuclear families with asthma } \\
\text { Subjects } \\
\text { Parents } \\
\text { Age, mean } \pm \text { SD, median }\end{array}$ & $\begin{array}{l}136 \\
540 \\
273 \\
39.37 \pm 6.51,39.0\end{array}$ \\
\hline $\begin{array}{l}\text { Smokers among parents, } n(\%) \\
\text { Active } \\
\text { Passive } \\
\text { Non-smokers } \\
\text { Parents with allergic bronchial asthma } \\
\text { Parents with total IgE } \geq 100 \mathrm{kU} / \mathrm{l}, n(\%) \\
\text { Parents with sensitization to cat (e1) } \\
\text { Parents with sensitization to dog (e2) } \\
\text { Parents with sensitization to } D \text {. pteronyssinus (d1) } \\
\text { Parents with sensitization to } D \text {. farinae (d2) } \\
\text { Children } \\
\text { Age, mean } \pm \text { SD, median } \\
\text { Sex, male: female }\end{array}$ & $\begin{array}{l}71(26.01 \%) \\
75(27.47 \%) \\
127(46.52 \%) \\
56(20.51 \%) \\
118(43.22 \%) \\
64(23.44 \%) \\
60(21.98 \%) \\
35(12.82 \%) \\
38(13.92 \%) \\
267 \\
12.92 \pm 5.58,13.0 \\
0.66: 0.34\end{array}$ \\
\hline $\begin{array}{l}\text { Children with allergic bronchial asthma } \\
\text { Affected sib trios } \\
\text { Affected sib pairs } \\
\text { Affected half-sibs }\end{array}$ & $\begin{array}{l}169 \text { ( } 63.30 \% \text { of all children }) \\
2 \\
31 \\
101\end{array}$ \\
\hline $\begin{array}{l}\text { Smokers among childre } \\
\text { Active } \\
\text { Passive } \\
\text { Non-smokers }\end{array}$ & $\begin{array}{r}30 \text { ( } 11.24 \% \text { of all children }) \\
86(32.21 \% \text { of all children }) \\
151(56.55 \% \text { of all children })\end{array}$ \\
\hline $\begin{array}{l}\text { Children with total IgE } \geq 100 \mathrm{kU} / \mathrm{l}, n(\%) \\
\text { Affected sib trios } \\
\text { Affected sib pairs } \\
\text { Affected half-sibs }\end{array}$ & $\begin{array}{l}153 \text { ( } 57.30 \% \text { of all children }) \\
5 \\
34 \\
70\end{array}$ \\
\hline $\begin{array}{l}\text { Children with sensitization to cat (e1) } \\
\text { Affected sib trios } \\
\text { Affected sib pairs } \\
\text { Affected half-sibs }\end{array}$ & $\begin{array}{l}115 \text { ( } 43.07 \% \text { of all children }) \\
2 \\
28 \\
53\end{array}$ \\
\hline $\begin{array}{l}\text { Children with sensitization to dog (e2) } \\
\text { Affected sib pairs } \\
\text { Affected half-sibs }\end{array}$ & $\begin{array}{l}89 \text { ( } 33.33 \% \text { of all children) } \\
25 \\
39\end{array}$ \\
\hline $\begin{array}{l}\text { Children with sensitization to D. pteronyssinus (d1) } \\
\text { Affected sib pairs } \\
\text { Affected half-sibs }\end{array}$ & $\begin{array}{l}55(20.60 \% \text { of all children }) \\
8 \\
39\end{array}$ \\
\hline $\begin{array}{l}\text { Children with sensitization to D. farinae (d2) } \\
\text { Affected sib pairs } \\
\text { Affected half-sibs }\end{array}$ & $\begin{array}{l}50 \text { ( } 18.73 \% \text { of all children }) \\
5 \\
40\end{array}$ \\
\hline
\end{tabular}

a At least one member of the family was diagnosed with asthma (according to GINA 2002).

\subsection{Estimation of total and specific $\operatorname{Ig} E$}

Collection of blood samples was conducted in 2004-2007 excluding summer months (pollination season). Total IgE levels were measured by ELISA using the kit IgE-EIA-BEST-strip (Cat. no. A-8660) (VECTOR-BEST, Novosibirsk, Russia). Total IgE levels were determined using the ELISA reader Uniplan (PICON, Moscow, Russia). Specific IgEs to cat (e1), dog (e2), and dust mite Dermatophagoides pteronyssinus (d1) and Dermatophagoides farinae ( $\mathrm{d} 2$ ) allergens were estimated by in vitro test system (Cat. no. DP-3110-1609 E) EUROLINE (EUROIMMUN AG, Medizinische Labordiagnostika GmbH, Lübeck, Germany). In this system allergen extracts on membrane strips and three control bands of different color intensity are used for detection and quantification of specific IgEs. We used the conditions recommended by the manufacturer with slight modifications. In brief, the strips were blocked in the kit "universal buffer" for $5 \mathrm{~min}$ at the room temperature. After blocking, each strip was incubated overnight in the cold room in $1 \mathrm{ml}$ of serum diluted 1:10 in universal buffer $(100 \mu \mathrm{l}$ of serum per $1 \mathrm{ml}$ of universal buffer) on rocking shaker 3D 
Rocking Platform STR9 (Stuart Scientific/Keison Products, Essex, UK). After the incubation, strips were washed by the $1 \mathrm{ml}$ of kit universal buffer on rocking shaker 3 times for $5 \mathrm{~min}$. Further, strips with attached antibodies were incubated with enzyme conjugate (alkaline-phosphatase-labeled anti-human IgE antibodies) on rocking shaker for $1 \mathrm{~h}$ and then washed by the kit universal buffer 4 times for $5 \mathrm{~min}$. Subsequently the strips were incubated $10 \mathrm{~min}$ with $1 \mathrm{ml}$ of NBT/BCIP (nitrobluetetrazoliumchloride/5-bromo-4chloro-3-indolylphosphate) to promote color reaction. The color reaction was stopped after $10 \mathrm{~min}$ by strip washing in distilled water. Damp strips were attached to the adhesive foil on the green protocol paper sheet (EUROIMMUN AG, Lübeck, Germany). After the strips were completely dry, they were scanned using USB flatbed scanner CanoScan LIDE 30 (Canon, Newport News, VA, USA) and EUROLINE Scan software for quantitative evaluation of the EUROLINE test strips. The levels of specific IgEs were determined using EUROLINE Scan software and three standard color bands. The lowest threshold of detection was $0.35 \mathrm{kU} / \mathrm{l}$.

Manufacturer's tests have shown that IgE levels obtained by EUROLINE system correlate with levels obtained by CAP system from Phadia (Uppsala, Sweden) (http://www.euroimmun.de/fileadmin/template/images/pdf/Allergie_6S_EN.pdf). We performed our own parallel comparative study of the two methods and confirmed this information. We measured levels of IgEs to dust mites (d2) and timothy grass (g6) in 112 samples by EUROIMMUN and Phadia CAP system and compared the obtained values using the non-parametric Spearman Correlation analysis (STATISTICA 8.0, StatSoft, Inc. 1984-2007, Tulsa, OK, USA). We found high correlation in IgE concentrations estimated by these two systems $R=0.87$, $P<0.009$ and $R=0.92, P<0.009$ for $\mathrm{d} 2$ and g6, respectively (data not shown).

\subsection{Genetic markers}

For the analysis, 21 STR markers located at different chromosomes/chromosomal regions were selected (Table 1) from the National Centre for Biotechnology Information (NCBI) database (http://www.ncbi.nih.gov). The STR markers are characterized in the Marshfield genetic map and show high heterozygosity. All markers are located in atopy candidate regions previously described in genome-wide studies of atopy and/or asthma $[2-12,19,18]$ (Table 1 ). Markers selected in regions 2q14.1 [20], 5q31.1 [5], 5q33.2 [3], 6p21.31 [8], 7p14.3 [7,10,11], 7q21.3 [2], 12q21.31 [14], 16q24.1 [18], and $19 q 13.33$ [32] were those that detected linkage in previous studies, and in regions $11 \mathrm{q} 12.1$ [31] and 16q12.2 [7,19] in close proximity of such markers. To test $13 \mathrm{q} 14.2$ and $20 \mathrm{p} 13$, we selected the nearest polymorphic STR marker to the genes PHF11 [24] and ADAM33 [25], respectively. Chromosome 12q harbors multiple genetic loci related to asthma and asthma-associated phenotypes, distinct peaks of linkage being observed in different populations [33]. Four markers in regions 12q14.1, 12q21.31, 12q23.1, and 12q24.3 (D12S1298, D12S379 [13,14], D12S1059, and D12S1282, respectively) were chosen in positions that would enable to test presence of described linkages in the studied population. After identification of a linkage with atopy to 12 q24.3 at $136.82 \mathrm{cM}$, we selected five additional STRs from surrounding regions (D12S338 at 111.87 cM, D12S164 at 119.55 cM, D12S2082 at 130.94 cM, D12S1611 at $140.17 \mathrm{cM}$, and D12S1634 at $148.24 \mathrm{cM}$ ) to establish the position of the susceptibility locus more precisely.

\subsection{Genotyping}

The primer sequences were obtained from the NCBI database. We used Cy5 carbocyanine dye 5'-end-labeled forward primers and unlabeled reverse primers synthesized by Generi-Biotech s.r.o. (Hradec Králové, Czech Republic) or Sigma-Genosys Ltd. (Stein-
Table 3

Linkage results for asthma, total and specific IgE, and spirometric indices.

\begin{tabular}{|c|c|c|c|c|}
\hline Locus & $\begin{array}{l}\text { cM } \\
\text { (Marshfield) }\end{array}$ & Marker & $\begin{array}{l}\text { Linkage in families } \\
\text { with asthma } \\
\text { LOD }^{\mathrm{a}} / P \text {-level }\end{array}$ & Phenotype \\
\hline $6 \mathrm{p} 21.31$ & 49.5 & D6S291 & $1.04 / 0.014$ & Asthma \\
\hline $12 q 23.1$ & 105.18 & D12S1059 & $1.01 / 0.02$ & Cat-specific IgE \\
\hline $12 \mathrm{q} 23.3$ & 111.87 & D12S338 & $\begin{array}{l}1.28 / 0.008 \\
1.21 / 0.009\end{array}$ & $\begin{array}{l}\text { Cat-specific IgE } \\
\text { FEV1 (\%) }\end{array}$ \\
\hline $12 q 24.22$ & 130.94 & D12S2082 & $1.01 / 0.02$ & Cat-specific IgE \\
\hline $12 q 24.3$ & $\begin{array}{l}136.82 \\
140.17\end{array}$ & $\begin{array}{l}\text { D12S1282 } \\
\text { D12S1611 }\end{array}$ & $\begin{array}{l}1.76 / 0.002 \\
2.23 / 0.0007 \\
1.12 / 0.012\end{array}$ & $\begin{array}{l}\text { Cat-specific IgE } \\
\text { Cat-specific IgE } \\
\text { Total IgE }\end{array}$ \\
\hline $13 q 14.2$ & 45.55 & D13S165 & $1.05 / 0.014$ & Total IgE \\
\hline
\end{tabular}

a Only LOD scores $>1.0$ are shown.

heim, Germany). DNA was amplified in a $10-\mu 1$ PCR reaction using universal program described in detail elsewhere [34]. PCR products were separated by $\mathrm{CEQ}^{\mathrm{TM}} 8800$ Genetic Analysis System (Beckman Coulter Inc., Fullerton, CA, USA). All inconclusive genotypes were excluded (less than $2.2 \%$ for each marker).

\subsection{Statistical analysis}

The statistical analysis included all family members (also probands) regardless of affected status. Non-parametric linkage analysis for co-segregation of a chromosomal region and a trait of interest (qualitative and quantitative) was performed. The analysis is based on the calculation of LOD score using the Kong and Cox linear model [35]. This method allows using small nuclear families and calculation of linkage without assuming the normal distribution of the studied trait. We used the Whittemore and Halpern NPL pairs statistics [36] to test for allele sharing among affected individuals. The computer program MERLIN version 1.0.0 - (c) 2000-2005 [37] was used for calculation of allele frequencies (across all individuals) and LOD scores. Sex, age and smoking were covariates in all calculations.

\section{Results}

The most significant results were obtained for the candidate region on chromosome 12 (Table 3 ). Initially we tested four markers in regions 12q14.1,12q21.31, 12q23.1, and 12q24.3 (D12S1298, D12S379, D12S1059, and D12S1282, respectively). Multipoint linkage analysis showed some evidence of linkage of cat-specific IgE with marker D12S1282 at the position $136.82 \mathrm{cM}$ in $12 \mathrm{q} 24.3$ chromosomal region $(\mathrm{LOD}=1.46, P=0.005)$. To localize the locus of linkage more precisely we have tested five additional STRs (D12S338 at $111.87 \mathrm{cM}, \mathrm{D} 12 \mathrm{~S} 1645$ at $119.55 \mathrm{cM}, \mathrm{D} 12 \mathrm{~S} 2082$ at $130.94 \mathrm{cM}$, D12S1611 at $140.17 \mathrm{cM}$, and D12S1634 at $148.24 \mathrm{cM}$ ) from the regions surrounding the marker D12S1282. This analysis revealed a locus controlling cat-specific IgE with a peak of linkage in an interval between 136 and $140 \mathrm{cM}$ (markers D12S1282 - LOD = 1.76, $P=0.002$ and D12S1611 - LOD = 2.23, $P=0.0007$ ) in 12q24.3 (Table 3) (Fig. 1). The linkage of the adjacent marker D12S2082 $(130.94 \mathrm{cM})$ exceeded LOD $>1.0$ (LOD =1.01, $P=0.02$ ). Total IgE showed indications of linkage at 12q24.3 with marker D12S1611 (LOD = 1.12, $P=0.012$ ) (Table 3) (Fig. 1), the peak of linkage being the same as for cat-specific IgE. On the other hand, peak of linkage with spirometric index FEV1 (\%) was observed at the more proximal position of $111.87 \mathrm{cM}$ to the marker D12S338 - $\operatorname{LOD}=1.21, P=0.009$. The linkage of cat-specific IgE to this marker also exceeded LOD $>1$ (Table 3 ). Some evidence of linkage (LOD > 1.0) was also detected to asthma at 6p21.31 (D6S291 - $\mathrm{LOD}=1.04, P=0.014$ ) and to total IgE at 13q14.2 (D13S165 LOD $=1.05, P=0.014$ ) (Table 3$)$. 


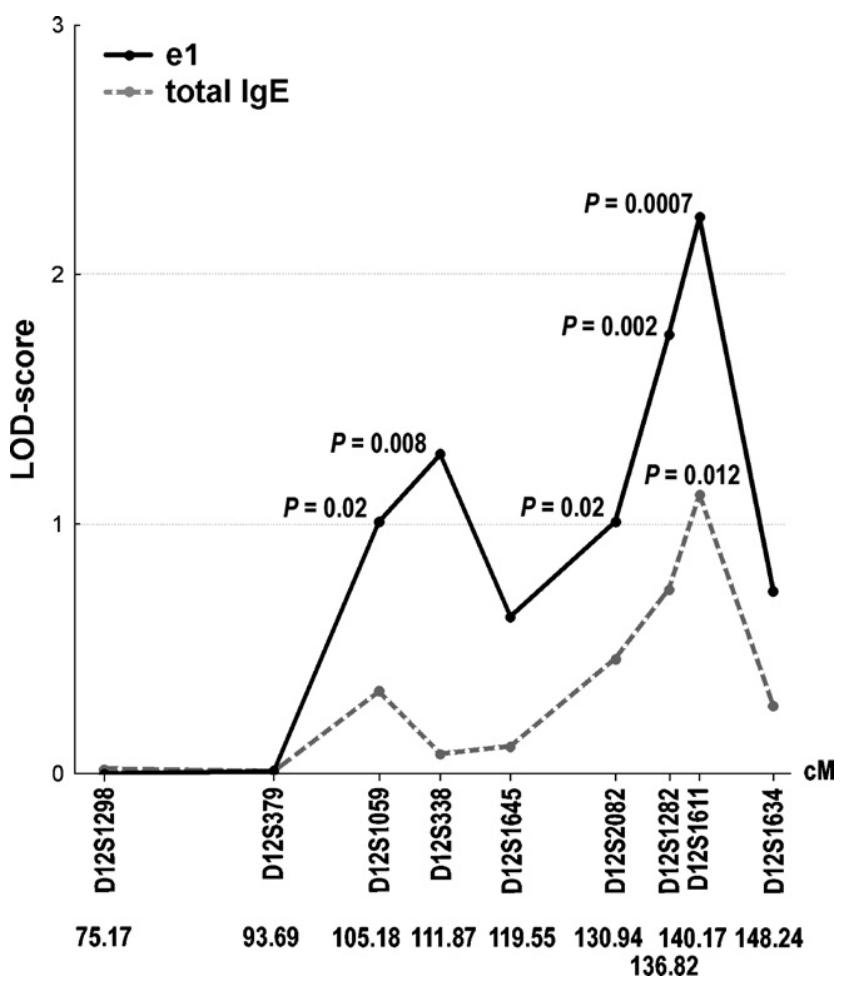

Fig. 1. Linkage of total IgE and cat-specific IgE to markers on chromosome 12q24.

We did not detect linkage of specific IgE to dog and dust mites, and of FVC (\%) and Tiffenau index to any of the tested markers.

\section{Discussion}

In the present study we have replicated evidence for an atopy susceptibility locus at the chromosomal region 12q24 in Russian patients with asthma from Siberia. We have observed a peak of a suggestive linkage at the positions of $136-140 \mathrm{cM}$ for cat-specific IgE and some evidence of linkage for total $\operatorname{IgE}$ at the same position. The linkage of the region 12 q24.3 (125-134 cM) with total IgE, asthma and wheeze, eosinophil count and airway responsiveness, was reported in Dutch [2,5] and Japanese [6], British [15], French [38] and Costa Rica Hispanic [17] population, respectively, supporting the important role of this locus in development of asthma and atopy related traits (Fig. 2). The locus at 136-140 cM linked to cat-specific IgE detected in the present study is located in a close proximity (within $9 \mathrm{cM}$ ) to the loci described above (Fig. 2) and confirms previous reports of atopy related loci at this site $[2,5,6,15,17,38]$.

We have not found a significant or a suggestive linkage of the locus on 12q24.3 with asthma. We report that asthma and different asthma sub-components are controlled by sets of loci that partly overlap, but are not identical (Table 3 ). Similar results were also obtained by others $[4,7-9,41]$. The difference in susceptibility to a specific sub-component of a complex trait in different human populations might be caused by different genetic composition, by different lifestyles and exposures and/or by environmental variations in major allergens triggering development of asthma. In the mouse model, studying genetically different mice in controlled environment, the various components of the pathogenetic pathway of allergic asthma (airway reactivity, serum IgE levels, cellular and cytokine composition of the broncho-alveolar lavage fluid) are under separate genetic control [43]. This may explain why in the present study and in other similar studies asthma is not necessarily linked to the genes that control one out of its sev- eral distinct pathogenetic components. The analysis of less complex and more exactly defined phenotypes such as levels of total and specific IgE is therefore an important part of genetics of asthma and other atopic diseases. Therefore analysis of susceptibility to asthma in different human populations may elucidate the prevalent population-specific pathogenic pathways and indicate the optimal preventive measures.

The peaks of linkage for cat-specific IgE and total IgE are at the same position (marker D12S1611), but linkage of a total IgE was weaker than linkage for cat-specific IgE. This can be explained by the fact that total IgE and cat-specific IgE correlate only partly $(R=0.36$, $P=0.00003$ ) [42]. These data also show importance of studies of different sub-phenotypes of complex traits because they are often under a distinct genetic control.

The locus 12q24.3 encompasses in the interval 136-140 cM a large gene cluster with several potential candidate genes (Fig. 2). The most promising target for a future research is a gene for interleukin-31 (IL31). IL-31 is a pro-inflammatory cytokine expressed preferentially by $\mathrm{CD}^{+}{ }^{+} \mathrm{T}$ helper (Th) type cells, which has been recently implicated as a good marker for allergic skin inflammation during atopic dermatitis [44] and bronchial inflammation during allergic asthma [44]. Increased levels of IL-31 mRNA were observed in biopsy specimens taken from patients with atopic dermatitis [44]. Similarly, mRNA levels of IL-31 were significantly higher in peripheral blood mononuclear cells of patients with asthma than in non-asthmatic healthy individuals [45] and correlated with the serum concentration of this cytokine [45]. It was reported that IL-31 mediates activation of bronchial epithelial cells, thereby contributing to bronchial inflammation during asthma [46]. All these data strongly indicate IL31 gene as the main candidate from the locus $12 \mathrm{q} 24.3(136-140 \mathrm{cM})$ for atopy and allergy development.

Three other candidate genes previously suggested in this locus include PLA2G1B (phospholipase A2, group IB) [47], NCOR2 (nuclear receptor co-repressor 2) [17], and UBC (ubiquitin C) [17]. Phospholipase A2 cleaves phospholipids and releases lysophosphatidylcholine plus free fatty acid, most commonly arachidonic acid, which can be metabolized to prostaglandins and leukotrienes. These molecules could be important mediators of the early phase of the asthmatic response to inhaled allergens and can also regulate Tcell trafficking that occurs in allergic pulmonary inflammation [48]. Nuclear receptor co-repressor (NCOR) is involved in control of broad subsets of AP-1 (activator protein 1) and NF- $\kappa B$ (nuclear factor kappa-B)-dependent gene networks that regulate diverse biological processes including inflammation and cell migration [49]. The attachment of ubiquitin chains targets proteins for proteosomal degradation and thus has ability to modulate immune responses, such as NF- $\kappa$ B activation and differentiation of $\mathrm{CD} 4^{+} \mathrm{T}$-cells into $\mathrm{T}$ helper 2 cells [50].

This is a first report indicating the role of the locus $12 \mathrm{q} 24.3$ in control of sensitization to cat allergens. Previous studies detected some evidence of linkage to cat-specific IgE to chromosomal region 11q13 in African American families with asthma [51] and to 12q22 in Czech atopic families [34]. Association studies indicated polymorphic variants in genes HLA-DRB1 (6p21.3) in Australian population [52], interleukin 4 receptor, alpha - IL4RA, polymorphism Gln551Arg (16p12) in German population [53], and chemokine ( $\mathrm{C}-\mathrm{C}$ motif) ligand 5 - CCL5/RANTES, polymorphism G401A (17q11.2-q12) and thromboxane A2 receptor - TBXA2R, polymorphism T924C (19p13.3) in Chinese population [54,55] that predispose to cat allergic sensitization in patients with asthma. The relatively limited phenotypic effects of the detected loci and genes suggest that they represent only a part of the extensive multigenic control of this trait. The genetic and environmental variation in different geographical areas might explain different genetic control of sensitization to cat allergens in different populations. 


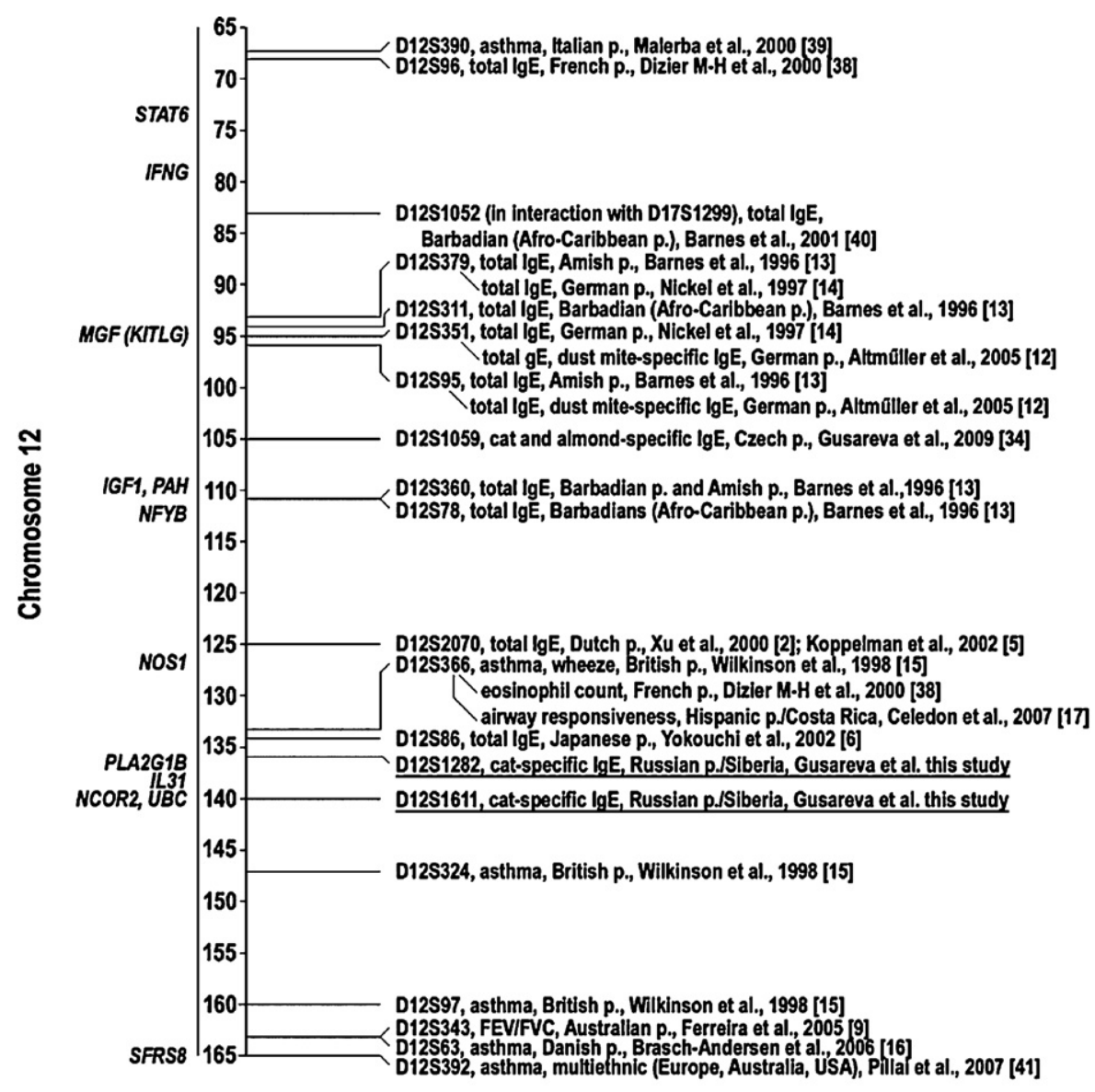

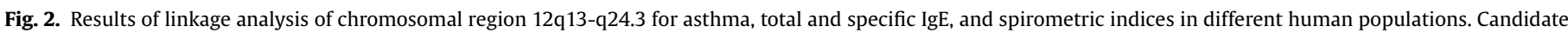

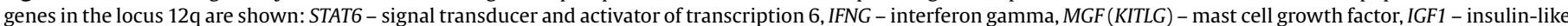

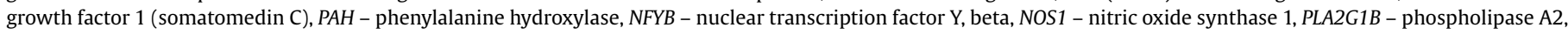
group IB, IL31 - interleukin-31, NCOR2 - nuclear receptor co-repressor 2, UBC - ubiquitin C, SFRS8 - splicing factor, arginine/serine-rich 8.

The present data describe the first genetic linkages to asthma related traits in the Russian population. They will also contribute to understanding of genetic control of sensitization to cat allergens.

\section{Acknowledgments}

We acknowledge the help of Evgenija V. Deeva, Olga S. Fedorova and Ivan A. Deev from Siberian State Medical University, Faculty of Pediatrics, Tomsk, Russia and Nadezhda V. Kazakevich from General Hospital of Thumen State Medical Academy, Thumen, Russia and many other clinical specialists in recruitment, interviews and clinical description of patients. Most important, we thank all the patients without whom this study would have been impossible to undertake.

This investigation was supported by the European Commission (INTAS Genomics 05-1000004-7761), Academy of Sciences of the Czech Republic (program grant AVOZ50520514), Grant Agency of the Czech Republic (grant GAČR 310/06/1745) and Ministry of Education of the Czech Republic (program grant LC06009).

\section{References}

[1] Wills-Karp M, Ewart SL. Time to draw breath: asthma-susceptibility genes are identified. Nat Rev Genet 2004;5:376-87.

[2] Xu J, Postma DS, Howard TD, Koppelman GH, Zheng SL, Stine OC, et al. Major genes regulating total serum immunoglobulin $\mathrm{E}$ in families with asthma. Am J Hum Genet 2000;67:1163-73.

[3] Yokouchi Y, Nukaga Y, Shibasaki M, Noguchi E, Kimura K, Ito S, et al. Significant evidence for linkage of mite-sensitive childhood asthma to chromosome 5q31-q33 near the interleukin 12 B locus by a genome-wide search in Japanese families. Genomics 2000:66:152-60.

[4] Haagerup A, Bjerke T, Schiotz PO, Binderup HG, Dahl R, Kruse TA. Asthma and atopy - a total genome scan for susceptibility genes. Allergy 2002;57:680-6.

[5] Koppelman GH, Stine OC, Xu J, Howard TD, Zheng SL, Kauffman HF, et al. Genome-wide search for atopy susceptibility genes in Dutch families with asthma. J Allergy Clin Immunol 2002;109:498-506.

[6] Yokouchi Y, Shibasaki M, Noguchi E, Nakayama J, Ohtsuki T, Kamioka M, et al. A genome-wide linkage analysis of orchard grass-sensitive childhood seasonal allergic rhinitis in Japanese families. Genes Immun 2002;3:9-13.

[7] Daniels SE, Bhattacharrya S, James A, Leaves NI, Young A, Hill MR, et al. A genome-wide search for quantitative trait loci underlying asthma. Nature 1996;383:247-50.

[8] Wjst M, Fischer G, Immervoll T, Jung M, Saar K, Rueschendorf F, et al. A genomewide search for linkage to asthma. Genomics 1999;58:1-8.

[9] Ferreira MA, O'Gorman L, Le Souëf P, Burton PR, Toelle BG, Robertson CF, et al. Robust estimation of experimentwise $P$ values applied to a genome scan of multiple asthma traits identifies a new region of significant linkage on chromosome 20q13. Am J Hum Genet 2005;77:1075-85.

[10] Laitinen T, Daly MJ, Rioux JD, Kauppi P, Laprise C, Petäys T, et al. A susceptibility locus for asthma-related traits on chromosome 7 revealed by genome-wide scan in a founder population. Nat Genet 2001;28:87-91.

[11] Shugart YY, Specchia C, Li HH, Doan BO, Mathias RA, Devoto M. Comparison of sib pair-based approaches for identifying quantitative trait loci underlying asthma in the Busselton families. Genet Epidemiol 2001;1:198-203.

[12] Altmüller J, Seidel C, Lee YA, Loesgen S, Bulle D, Friedrichs F, et al. Phenotypic and genetic heterogeneity in a genome-wide linkage study of asthma families. BMC Pulm Med 2005;5:1.

[13] Barnes KC, Neely JD, Duffy DL, Freidhoff LR, Breazeale DR, Schou C, et al. Linkage of asthma and total serum IgE concentration to markers on chromosome 12q: evidence from Afro-Caribbean and Caucasian populations. Genomics 1996;37:41-50.

[14] Nickel R, Wahn U, Hizawa N, Maestri N, Duffy DL, Barnes KC, et al. Evidence for linkage of chromosome 12q15-q24.1 markers to high total serum IgE concentrations in children of the German Multicenter Allergy Study. Genomics 1997;46:159-62. 
[15] Wilkinson J, Grimley S, Collins A, Thomas NS, Holgate ST, Morton N. Linkage of asthma to markers on chromosome 12 in a sample of 240 families using quantitative phenotype scores. Genomics 1998;53:251-9.

[16] Brasch-Andersen C, Tan Q, Børglum AD, Haagerup A, Larsen TR, Vestbo J, et al. Significant linkage to chromosome 12q24.32-q24.33 and identification of SFRS8 as a possible asthma susceptibility gene. Thorax 2006;61:874-9.

[17] Celedón JC, Soto-Quiros ME, Avila L, Lake SL, Liang C, Fournier E, et al. Significant linkage to airway responsiveness on chromosome 12q24 in families of children with asthma in Costa Rica. Hum Genet 2007;120:691-9.

[18] Ober C, Tsalenko A, Parry R, Cox NJ. A second-generation genomewide screen for asthma-susceptibility alleles in a founder population. Am J Hum Genet 2000;67:1154-62.

[19] Kurz T, Strauch K, Heinzmann A, Braun S, Jung M, Ruschendorf F, et al. European study on the genetics of mite sensitisation. J Allergy Clin Immunol 2000;106:925-32.

[20] Allen M, Heinzmann A, Noguchi E, Abecasis G, Broxholme J, Ponting CP, et al. Positional cloning of a novel gene influencing asthma from chromosome $2 \mathrm{q} 14$. Nat Genet 2003;35:258-63.

[21] Howard TD, Postma DS, Hawkins GA, Koppelman GH, Zheng SL, Wysong AK, et al. Fine mapping of an IgE-controlling gene on chromosome $2 \mathrm{q}$ : analysis of CTLA4 and CD28. J Allergy Clin Immunol 2002;110:743-51.

[22] Whittaker PA. What is the relevance of bioinformatics to pharmacology? Trends Pharmacol Sci 2003;24:434-9.

[23] Laitinen T, Polvi A, Rydman P, Vendelin J, Pulkkinen V, Salmikangas P, et al. Characterization of a common susceptibility locus for asthma-related traits. Science 2004;304:300-4.

[24] Zhang Y, Leaves NI, Anderson GG, Ponting CP, Broxholme J, Holt R, et al. Positional cloning of a quantitative trait locus on chromosome $13 q 14$ that influences immunoglobulin E levels and asthma. Nat Genet 2003;34:181-6.

[25] van Eerdewegh P, Little RD, Dupuis J, Del Mastro RG, Falls K, Simon J, et al. Association of the ADAM33 gene with asthma and bronchial hyperresponsiveness. Nature 2002;418:426-30.

[26] Moffatt MF, Kabesch M, Liang L, Dixon AL, Strachan D, Heath S, et al. Genetic variants regulating ORMDL3 expression contribute to the risk of childhood asthma. Nature 2007;448:470-3.

[27] Ober C, Tan Z, Sun Y, Possick JD, Pan L, Nicolae R, et al. Effect of variation in CHI3L1 on serum YKL-40 level, risk of asthma, and lung function. N Engl J Med 2008;358:1682-91.

[28] Gusareva ES, Bragina EJ, Deeva EV, Kazakevich NV, Puzyrev VP, Ogorodova LM, et al. Cat is a major allergen in patients with asthma from west Siberia, Russia. Allergy 2006;61:509-10.

[29] Hugg TT, Jaakkola MS, Ruotsalainen R, Pushkarev V, Jaakkola JJ. Exposure to animals and the risk of allergic asthma: a population-based cross-sectional study in Finnish and Russian children. Environ Health 2008;7:28.

[30] Quanjer PH, Tammeling GJ, Cotes JE, Pedersen OF, Peslin R, Yernault JC. Lung volumes and forced ventilatory flows. Report working party standardization of lung function tests, European community for steel and coal. Official Statement of the European Respiratory Society. Eur Respir J Suppl 1993;16: $5-40$.

[31] Adra CN, Mao XQ, Kawada H, Gao PS, Korzycka B, Donate JL, et al. Chromosome $11 \mathrm{q} 13$ and atopic asthma. Clin Genet 1999;55:431-7.

[32] Venanzi S, Malerba G, Galavotti R, Lauciello MC, Trabetti E, Zanoni G, et al. Linkage to atopy on chromosome 19 in north-eastern Italian families with allergic asthma. Clin Exp Allergy 2001;31:1220-4.

[33] Raby BA, Silverman EK, Lazarus R, Lange C, Kwiatkowski DJ, Weiss ST. Chromosome $12 \mathrm{q}$ harbors multiple genetic loci related to asthma and asthma-related phenotypes. Hum Mol Genet 2003;12:1973-9.

[34] Gusareva ES, Havelková H, Blažková H, Kosařová M, Kučera P, Král V, et al. Mouse to human comparative genetics reveals a novel immunoglobulin $\mathrm{E}$ - controlling locus on Hsa8q12. Immunogenetics 2009;61:15-25.

[35] Kong A, Cox NJ. Allele-sharing models: LOD scores and accurate linkage tests. Am J Hum Genet 1997;61:1179-88.
[36] Whittemore AS, Halpern J. A class of tests for linkage using affected pedigree members. Biometrics 1994;50:118-27.

[37] Abecasis GR, Cherny SS, Cookson WO, Cardon LR. Merlin - rapid analysis of dense genetic maps using sparse gene flow trees. Nat Genet 2002;30:97-101.

[38] Dizier MH, Besse-Schmittler C, Guilloud-Bataille M, Annesi-Maesano I, Boussaha $M$, Bousquet J, et al. Genome screen for asthma and related phenotypes in the French EGEA study. Am J Respir Crit Care Med 2000;162:1812-8.

[39] Malerba G, Lauciello MC, Scherpbier T, Trabetti E, Galavotti R, Cusin V, et al. Linkage analysis of chromosome 12 markers in Italian families with atopic asthmatic children. Am J Respir Crit Care Med 2000;162:1587-90.

[40] Barnes KC, Mathias RA, Nickel R, Freidhoff LR, Stockton ML, Xue X, et al. Testing for gene-gene interaction controlling total IgE in families from Barbados: evidence of sensitivity regarding linkage heterogeneity among families. Genomics 2001;71:246-51.

[41] Pillai SG, Chiano MN, White NJ, Speer M, Barnes KC, Carlsen K, et al. A genomewide search for linkage to asthma phenotypes in the genetics of asthma international network families: evidence for a major susceptibility locus on chromosome 2p. Eur J Hum Genet 2006;14:307-16 [erratum in: Eur J Hum Genet 2007; $15: 714$

[42] Gusareva ES, Ogorodova LM, Chernyak BA, Lipoldová M. Relationship between total and specific IgE in patients with asthma from Siberia. J Allergy Clin Immunol 2008;121:781.

[43] Piavaux B, Jeurink PV, Groot PC, Hofman GA, Demant P, Van Oosterhout AJ Mouse genetic model for antigen-induced airway manifestations of asthma. Genes Immun 2007;8:28-34.

[44] Neis MM, Peters B, Dreuw A, Wenzel J, Bieber T, Mauch C, et al. Enhanced expression levels of IL-31 correlate with IL-4 and IL-31 in atopic and allergic contact dermatitis. J Allergy Clin Immunol 2006;118:930-7.

[45] Lei Z, Liu G, Huang O, Lv M, Zu R, Zhang GM, et al. SCF and IL-31 rather than IL-17 and BAFF are potential indicators in patients with allergic asthma. Allergy 2008;63:327-32.

[46] Ip WK, Wong CK, Li ML, Li PW, Cheung PF, Lam CW. Interleukin-31 induces cytokine and chemokine production from human bronchial epithelial cells through activation of mitogen-activated protein kinase signalling pathways: implications for the allergic response. Immunology 2007;122:532-41.

[47] Holgate ST. The genetic basis of allergic disease. In: Holgate ST, Church MK Lichtenstein LM, editors. Allergy. third ed. Elsevier Ltd.; 2006. p. 205-21.

[48] Luster AD, Tager AM. T-cell trafficking in asthma: lipid mediators grease the way. Nat Rev Immunol 2004:4:711-24.

[49] Glass CK, Ogawa S. Combinatorial roles of nuclear receptors in inflammation and immunity. Nat Rev Immunol 2006;6:44-55.

[50] Liu YC, Penninger J, Karin M. Immunity by ubiquitylation: a reversible process of modification. Nat Rev Immunol 2005;5:941-52.

[51] Hizawa N, Freidhoff LR, Ehrlich E, Chiu YF, Duffy DL, Schou C, et al. Genetic influences of chromosomes 5q31-q33 and 11q13 on specific IgE responsiveness to common inhaled allergens among African American families. Collaborative Study on the Genetics of Asthma (CSGA). J Allergy Clin Immunol 1998; 102:449-53.

[52] Moffatt MF, Schou C, Faux JA, Abecasis GR, James A, Musk AW, et al. Association between quantitative traits underlying asthma and the HLA-DRB1 locus in a family-based population sample. Eur J Hum Genet 2001;9:341-6.

[53] Liu X, Beaty TH, Deindl P, Huang SK, Lau S, Sommerfeld C, et al. Associations between specific serum IgE response and 6 variants within the genes IL4, IL13, and IL4RA in German children: the German Multicenter Atopy Study. J Allergy Clin Immunol 2004;113:489-95.

[54] Leung TF, Tang NL, Lam CW, Li AM, Fung SL, Chan IH, et al. RANTES G-401A polymorphism is associated with allergen sensitization and FEV1 in Chinese children. Respir Med 2005;99:216-9.

[55] Leung TF, Tang NL, Lam CW, Li AM, Chan IH, Ha G. Thromboxane A2 recepto gene polymorphism is associated with the serum concentration of cat-specific immunoglobulin $\mathrm{E}$ as well as the development and severity of asthma in Chinese children. Pediatr Allergy Immunol 2002;13:10-7. 